\title{
Regional Assessment of Sewage Contamination in Sediments of the Iguaçu and the Barigui Rivers (Curitiba City, Paraná, Southern Brazil) using Fecal Steroids
}

\author{
Lucas Puerari, ${ }^{a}$ Renato S. Carreira, ${ }^{*, b}$ Artur C. B. Neto, ${ }^{a}$ Lilian C. Albarello ${ }^{a}$ and \\ Fabiana D. C. Gallotta ${ }^{c}$ \\ ${ }^{a}$ Instituto de Geociências, Universidade Federal do Rio Grande do Sul, \\ Av. Bento Gonçalves, 9500, CP 15001, 91501-970 Porto Alegre-RS, Brazil \\ ${ }^{b}$ Departamento de Química, Pontifícia Universidade Católica do Rio de Janeiro, \\ Rua Marquês de São Vicente, 225, 22453-900 Rio de Janeiro-RJ, Brazil \\ ${ }^{c}$ Centro de Pesquisas da Petrobras (CENPES), \\ Av. Horácio Macedo, 950, 21941-15 Rio de Janeiro-RJ, Brazil
}

\begin{abstract}
Esteroides derivados de fontes fecal (coprostanol, epicoprostanol e coprostanona) e mista (colesterol, colestanol e colestanona) foram analisados em 19 amostras de sedimentos superficiais, coletados em duas amostragens, por cromatografia gasosa com detector de ionização de chama (GC/FID) para prover uma avaliação regional da contaminação por esgotos nos Rios Iguaçu e Barigui, no Sul do Brasil. As concentrações médias de coprostanol na coleta de verão $\left(109 \pm 122 \mu \mathrm{g} \mathrm{g}^{-1}\right)$ e na de inverno $\left(130 \pm 116 \mu \mathrm{g} \mathrm{g}^{-1}\right)$ em 2007, com máximo de ca. $330 \mu \mathrm{g} \mathrm{g}^{-1}$, caracterizam os sedimentos como altamente contaminados por material fecal. Razões diagnósticas usando compostos selecionados sugeriram que os efluentes domésticos são a principal fonte de contaminação, embora o esterco produzido em áreas rurais possa ter importância localizada. Os resultados mostraram que o lançamento de esgotos não tratados pode representar um risco para a saúde ambiental do sistema fluvial quando a capacidade do sistema para dispersar e diluir efluentes é reduzida em períodos de baixo fluxo de água.
\end{abstract}

Steroids derived from fecal (coprostanol, epicoprostanol and coprostanone) and mixed (cholesterol, cholestanol and cholestanone) sources were analyzed in 19 surface sediments collected in two samplings by gas chromatography with flame ionization detection (GC/FID) in order to provide a regional assessment of the sewage contamination in the Iguaçu and Barigui Rivers, Southern Brazil. The mean concentrations of coprostanol in the Summer $\left(109 \pm 122 \mu \mathrm{g} \mathrm{g}^{-1}\right)$ and Winter $\left(130 \pm 116 \mu \mathrm{g} \mathrm{g}^{-1}\right)$ seasons in 2007 , with maximum value of approximately $330 \mu \mathrm{g} \mathrm{g}^{-1}$, situate the studied sediments as heavily contaminated by sewage. Diagnostic ratios among selected compounds suggested that domestic effluents were the main source of contamination, although the contribution of manure from livestock might also be locally important. The results show that the release of raw sewage may pose a relevant threat to the environmental health of river systems when the capacity to disperse and dilute the effluents is reduced during periods of small river water flow.

Keywords: sewage contamination, river sediments, molecular marker, coprostanol

\section{Introduction}

The input of domestic sewage, both treated and untreated, is a major concern regarding the contamination of aquatic environments. One reason for that is the large and increasing volume of sewage produced daily which is

*e-mail: carreira@puc-rio.br usually not followed by the necessary infrastructure of collection, treatment and adequate disposal of the effluents, particularly in developing and undeveloped countries. Moreover, in addition to solid and dissolved material (both organic and inorganic), which in turn may cause nutrient over-enrichment, oxygen depletion and decrease water transparency, sewage contains a complex mixture of organic and inorganic contaminants. ${ }^{1}$ Each class of 
contaminants present in sewage has distinct persistency, bioaccumulation potential and toxicity, including endocrine disrupting properties, all of which may pose a threat to biodiversity and ecosystem balance. ${ }^{1}$ Finally, the presence of sewage in aquatic systems is usually associated with high levels of pathogens and, thus, represents a risk to public health when the contaminated water is used for consumption, recreation or to the production of food., ${ }^{2,3}$

Bacteria of the coliform group, as well as fecal Streptococci, are indicators of fecal contamination commonly used to certify the condition of water bodies. ${ }^{4}$ However, to monitor the spatial dispersion and accumulation of sewage, it is necessary to select an indicator that has greater persistence in the environment than that presented by biological indicators. In this sense, specific molecules, known generically as anthropogenic molecular markers, are widely used as indicators of fecal contamination. Among several options, coprostanol ( $5 \beta$-cholestan-3 $\beta$-ol) has been used as marker of sewage contamination since the 1960s. This is a result of its specific source assignment, as coprostanol is a fecal sterol produced in the gut of warm blooded animals from the reduction of cholesterol, and because it is a relatively abundant compound, representing $60 \%$ of the total fecal sterols in humans. ${ }^{5}$ Epicoprostanol (a minor constituent of human feces but may be produced during sewage treatment) and coprostanone (present in human feces) are other steroids commonly quantified in studies of sewage contamination. ${ }^{5}$ Other compounds also considered in such studies are cholesterol, produced by planktonic organisms but also found in human feces, and cholestanol, a phytosterol. ${ }^{5}$ Chemical structures of compounds considered in the present work are presented in Figure 1.

Most of the studies conducted in Brazilian aquatic systems have focused on the distribution of sterols in estuaries and/or coastal bays, ${ }^{6-9}$ estuarine lagoons ${ }^{10}$ and lagoon systems, ${ }^{11,12}$ but rarely on exclusively fluvial systems. $^{13}$

In this study, it was investigated the regional distribution of steroids in sediments from the Iguaçu River and its tributary, the Barigui River. This investigation was conducted $10 \mathrm{~km}$ downstream of Curitiba, the Capital City of the Paraná State, up to a distance of approximately $70 \mathrm{~km}$ from this city. These rivers receive sewage loads from human settlements presenting different anthropogenic activities (urban, industrial and rural) along this distance. The sediments were collected in two periods (Summer and Winter in 2007), at stations in the main channels of the Iguaçu and the Barigui Rivers and some secondary channels of the Iguaçu River, and in a control station distant $200 \mathrm{~km}$ downstream.

\section{Experimental}

Study area, sampling strategy and in situ measurements

The Iguaçu is the main river in the Paraná State, Southern Brazil. This river is about 1,300 km long, from its headwaters in the Serra do Mar in the East to its confluence with the Paraná River in the West, covering a drainage basin of around $62,000 \mathrm{~km}^{2}$, with a mean annual water flow of $1,800 \mathrm{~m}^{3} \mathrm{~s}^{-1}{ }^{14}$ The climate in the region is sub-tropical, with humid conditions all over the year and with average precipitation ranging from 92 to $144 \mathrm{~mm}$, in the Winter and Summer, respectively.

At the study area (Figure 2), the river can be divided into two sections. On the upstream side, much of the river length has been channeled, with a width of around $40 \mathrm{~m}$ and depths ranging between 1.5 to $2.0 \mathrm{~m}$. From the point $\operatorname{Ig} 3$ onward,

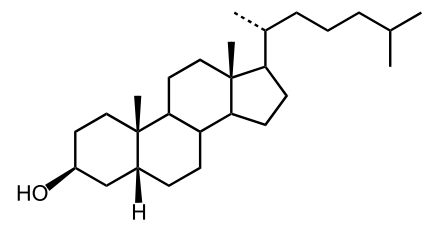

coprostanol

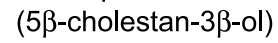

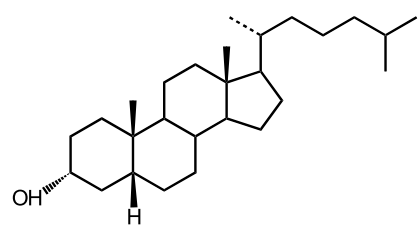

epicoprostanol

(5 $\beta$-cholestan-3 $\alpha$-ol)
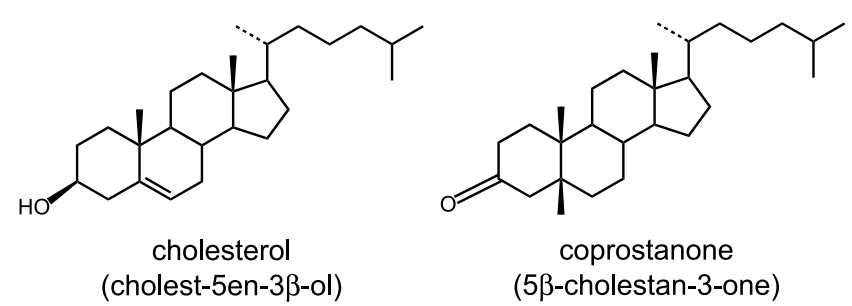

coprostanone

(5ß-cholestan-3-one)

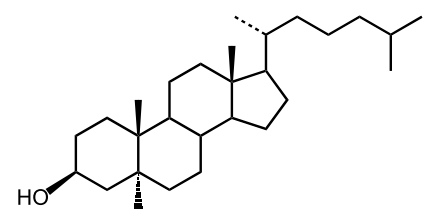

cholestanol

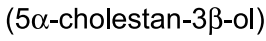

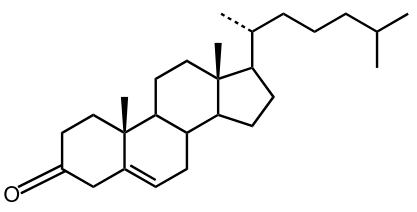

cholestanone (cholest-5en-3-one)

Figure 1. Chemical structures of the steroids quantified in the present work. 
the river flows on its natural bed, highly sinuous, with a broad flood plain, many secondary channels and abandoned meanders. The main channel of this section presents widths varying from 40 to $60 \mathrm{~m}$ and depths ranging from 1.4 to $3.0 \mathrm{~m}$. The Barigui River (Figure 2) is a tributary of the Iguaçu, with a length of $60 \mathrm{~km}$. In the study region, the channel width ranges from 15 to $20 \mathrm{~m}$, with depths from 0.20 to $0.50 \mathrm{~m}$, receiving contributions from the Saldanha Creek (Figure 2), which drains an important industrial area (e.g., oil refinery).

Sediments were sampled at 19 stations (Figure 2) and in two periods (January/2007 and July/2007). A Van Veen type dredge was used for sampling, and the surface layer $(0-2 \mathrm{~cm})$ of the sediment was carefully sub-sampled and stored in aluminum containers (previously decontaminated with dichloromethane). Samples were kept refrigerated in the field and stored frozen at $-20^{\circ} \mathrm{C}$ in the laboratory until analysis. Most of the sampling stations were positioned in the main channel of the Iguaçu and the Barigui Rivers, but stations Ig8, Ig10, Ig 12 and Ig13 were located in secondary channels (Figure 2). Station Ig15, used as a control station, was located near the União da Vitória City, around 200 $\mathrm{km}$ downstream the Araucária City. It is a region with agricultural activities (grain production) with no major urban settlement.

As the sampling may be considered limited (only two periods) and no replicate samples were collected. Because the sampling device mixes a sediment layer that may represent several years depending on local sedimentation rates, the results obtained in the present work represent two snapshots of the environmental condition in the fluvial system and no evaluation of seasonal trends in steroids distribution can be done.

\section{Determination of total organic carbon (TOC)}

TOC analysis was performed by oxidation with sodium persulfate at high temperature. The $\mathrm{CO}_{2}$ generated from the oxidation was absorbed in sodium hydroxide solution and determined by volumetry. ${ }^{15}$ Precision was higher than $15 \%$ based on 4 replicate analyses of a sediment sample.

\section{Determination of coprostanol and other steroids}

Detailed analytical conditions for the steroids analyses have been described elsewhere. ${ }^{6}$ Briefly, $10-20 \mathrm{~g}$ (precision of $0.001 \mathrm{~g}$ ) of wet sediment were mixed with sodium sulfate (solvent extracted and dried at $105^{\circ} \mathrm{C}$ ) and Soxhlet extracted with $200 \mathrm{~mL}$ of a mixture of dichloromethane and methanol (2:1 v/v; pesticide grade; J. T. Baker) for $24 \mathrm{~h}$. Before extraction, $5.6 \mu \mathrm{g}$ androstanol ( $5 \alpha$-androstan-3 $\beta$-ol; $>95 \%$ purity; Sigma) were added to the samples as a surrogate standard. The bulk organic extract was reduced by rotary evaporation, and elemental $\mathrm{S}$ and water traces were removed using activated copper and anhydrous sodium sulfate, respectively.

The fraction containing the sterols was separated from the bulk organic extract by column chromatography on silica gel (5 g, 230-400 mesh, 5\% water deactivated; Merck) by elution with $24 \mathrm{~mL}$ of $10 \%$ methanol in dichloromethane. This fraction was concentrated by rotary evaporation and by a gentle stream of purified $\mathrm{N}_{2}$ and was then stored at $-20^{\circ} \mathrm{C}$ until analysis by gas chromatography with flame ionization detection (GC/FID).

Quantitative analyses of $1 \mu \mathrm{L}$ sample aliquots were performed in a GC/FID equipment (Hewlett-Packard model 6890). An HP-5 (5\% phenyl methyl siloxane)
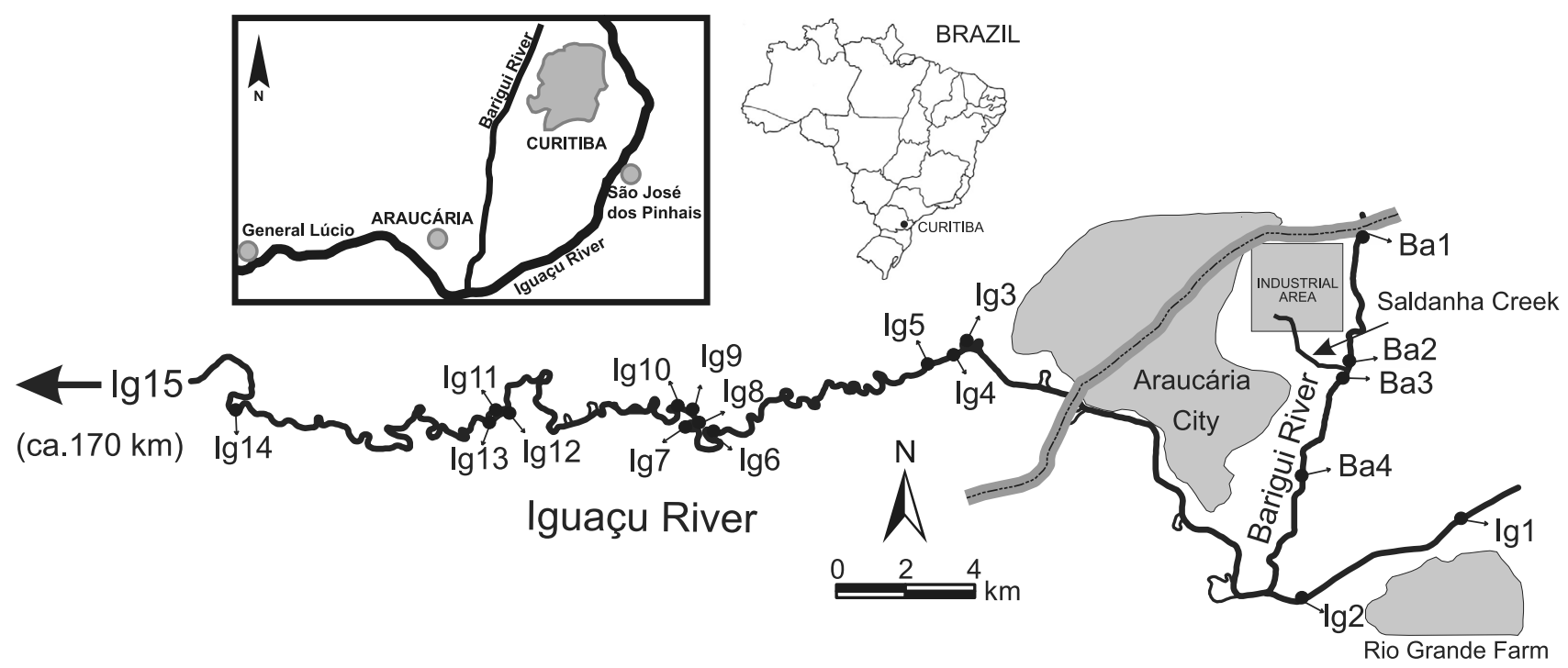

Figure 2. Study region and location at the sampling stations in the Iguaçu and the Barigui Rivers. 
capillary column with $30 \mathrm{~m}$ length, $0.32 \mathrm{~mm}$ i.d. and $0.25 \mu \mathrm{m}$ film thickness was used with $\mathrm{He}$ as the carrier gas (maintained at a constant flow rate of $1 \mathrm{~mL} \mathrm{~min}{ }^{-1}$ ). The column temperature was programmed from an initial $1 \mathrm{~min}$ hold at 60 to $250{ }^{\circ} \mathrm{C}$ at $15^{\circ} \mathrm{C} \mathrm{min}-1$ and then from 250 to $300{ }^{\circ} \mathrm{C}$ at $1{ }^{\circ} \mathrm{C} \mathrm{min}{ }^{-1}$, with a final hold of $5 \mathrm{~min}$. The injector and detector temperatures were set at 270 and $300{ }^{\circ} \mathrm{C}$, respectively. Prior to injection, the extracts were dried and the sterols were derivatized with $100 \mu \mathrm{L}$ of bis(trimethylsilyl)trifluoroacetamide (BSTFA; Sigma) at $80{ }^{\circ} \mathrm{C}$ for $1 \mathrm{~h}$. Cholestane $(5.0 \mu \mathrm{g} ;>95 \%$ purity; Sigma) was added to the final extract, as an internal standard for quantification.

Authentic standards of androstanol (surrogate standard), coprostanol, epi-coprostanol, cholesterol, cholestanol, coprostanone and cholestanone were obtained from SigmaAldrich, Poole, UK. All standards were 95\% pure or higher. Quantification was based on the response factors of each compound to the internal standard (cholestane). Calibration curves with five points in the range of 500 to $10,000 \mathrm{ng} \mathrm{mL}^{-1}$ were constructed to check for linearity $(r>0.999)$ of the instrumental response. Two of the standards from the calibration curve were also analyzed daily to check response factors and chromatographic parameters (retention times, peak shape and resolution). As certified reference materials for fecal sterols are not commercially available, quality control procedures involved the analysis of laboratory blanks (no contamination was observed), spiked samples $(n=3$; recovery higher than $80 \%$ for each compound) and check of surrogate standard recoveries (which varied between 70-85\% with standard-deviations below $15 \%$ ). Precision was higher than $20 \%$ for all fecal steroids, based on 4 replicate analyses of one sediment sample. The limit of quantification (LOQ) was estimated as $0.010 \mu \mathrm{g} \mathrm{g}^{-1}$, based on the instrument signal/noise ratio and by consideration of the mean mass of sediment extracted.

\section{Results and Discussion}

\section{Distribution of TOC and coprostanol}

In general, the TOC contents in the sediment were very similar in both samplings, with the same mean of $2.38 \%$ and ranging from 0.10 to $4.80 \%$ (Summer sampling) and 0.30 to $4.40 \%$ (Winter sampling) (Table 1). However, a considerable variation in TOC concentrations was observed at stations $\mathrm{Ba} 3, \operatorname{Ig} 4, \operatorname{Ig} 7$ and $\operatorname{Ig} 8$ in both samplings. Since it was conducted only two samplings without sample

Table 1. Distribution of total organic carbon (TOC) and fecal steroids in sediments collected twice (Summer and Winter 2007) in the Iguaçu and the Barigui River systems (<LOQ: less than the limit of quantification or $0.010 \mu \mathrm{g} \mathrm{g}^{-1}$ )

\begin{tabular}{|c|c|c|c|c|c|c|c|c|c|c|c|c|c|c|}
\hline & \multicolumn{2}{|c|}{ TOC / \% } & \multicolumn{2}{|c|}{$\begin{array}{c}\text { Coprostanol / } \\
\left(\mu \mathrm{g} \mathrm{g}^{-1}\right)\end{array}$} & \multicolumn{2}{|c|}{$\begin{array}{c}\text { Epicoprostanol / } \\
\left(\mu \mathrm{g} \mathrm{g}^{-1}\right)\end{array}$} & \multicolumn{2}{|c|}{$\begin{array}{c}\text { Cholesterol / } \\
\left(\mu \mathrm{g} \mathrm{g}^{-1}\right)\end{array}$} & \multicolumn{2}{|c|}{$\begin{array}{c}\text { Cholestanol / } \\
\left(\mu \mathrm{g} \mathrm{g}^{-1}\right)\end{array}$} & \multicolumn{2}{|c|}{$\begin{array}{l}\text { Coprostanone / } \\
\left(\mu \mathrm{g} \mathrm{g}^{-1}\right)\end{array}$} & \multicolumn{2}{|c|}{$\begin{array}{l}\text { Colestanone / } \\
\left(\mu \mathrm{g} \mathrm{g}^{-1}\right)\end{array}$} \\
\hline & Summer & Winter & Summer & Winter & Summer & Winter & Summer & Winter & Summer & Winter & Summer & Winter & Summer & Winter \\
\hline Ba1 & 0.9 & 0.3 & 9.21 & 26.5 & 0.54 & 0.6 & 5.45 & 15.6 & 2.14 & 4.82 & 0.37 & 4.8 & $<\mathrm{LOQ}$ & 0.72 \\
\hline $\mathrm{Ba} 2$ & 1.0 & 1.5 & 14.2 & 9.0 & 1.02 & $<\mathrm{LOQ}$ & 12.9 & 5.9 & 4.81 & 1.63 & 5.18 & 1.4 & $<\mathrm{LOQ}$ & $<\mathrm{LOQ}$ \\
\hline $\mathrm{Ba} 3$ & 0.1 & 1.2 & 0.75 & 64.7 & 0.04 & 1.5 & 0.61 & 12.6 & 0.28 & 9.71 & 0.28 & 11.9 & $<\mathrm{LOQ}$ & 1.06 \\
\hline $\mathrm{Ba} 4$ & 0.1 & 0.6 & 0.73 & 3.7 & 0.15 & $<\mathrm{LOQ}$ & 6.3 & 2.0 & 0.38 & 0.56 & 0.31 & 0.6 & $<\mathrm{LOQ}$ & $<\mathrm{LOQ}$ \\
\hline $\operatorname{Ig} 1$ & 2.2 & 1.9 & 1.87 & 71.4 & 1.92 & 1.7 & 2.25 & 2.3 & 6.93 & 19.3 & 3.26 & 16.9 & $<\mathrm{LOQ}$ & 2.32 \\
\hline $\operatorname{Ig} 2$ & 3.9 & 4.4 & 249 & 29.9 & 10.8 & 0.7 & 81.8 & 14.6 & 50.0 & 5.29 & 11.6 & 6.3 & $<\mathrm{LOQ}$ & 0.54 \\
\hline $\operatorname{Ig} 3$ & 3.7 & 2.8 & 229 & 330 & 16.6 & 9.6 & 58.5 & 58.8 & 57.5 & 66.2 & 80.6 & 64.4 & 16.3 & 6.52 \\
\hline $\operatorname{Ig} 4$ & 0.6 & 2.5 & 11.8 & 124 & 0.86 & 1.0 & 13.4 & 81.4 & 3.07 & 11.5 & 5.97 & 15.3 & 0.84 & $<\mathrm{LOQ}$ \\
\hline $\operatorname{Ig} 5$ & 2.5 & 1.3 & 65.8 & 154 & 3.51 & 1.9 & 3.07 & 253 & 2.14 & 21.1 & 18.4 & 27.3 & 4.03 & 2.41 \\
\hline $\operatorname{Ig} 6$ & 3.9 & 3.4 & 81.3 & 169 & 6.05 & 3.4 & 1.59 & 109 & 1.11 & 18.2 & 27.3 & 28.3 & 5.03 & 4.17 \\
\hline $\operatorname{Ig} 7$ & 0.8 & 4.3 & 8.52 & 262 & 0.48 & 16.2 & 0.24 & 51.3 & 0.16 & 55.7 & 2.64 & 66.6 & 0.47 & 10.8 \\
\hline $\operatorname{Ig} 8$ & 4.8 & 2.1 & 109 & 51.4 & 5.61 & 0.9 & 37.0 & 17.9 & 18.3 & 2.93 & 26.6 & 8.3 & 6.73 & 1.73 \\
\hline $\operatorname{Ig} 9$ & 4.0 & 3.4 & 189 & 307 & 10.5 & 16.3 & 3.38 & 113 & 2.36 & 56.5 & 47.6 & 66.7 & 8.04 & 9.82 \\
\hline $\operatorname{Ig} 10$ & 2.1 & 2.4 & 26.3 & 29.2 & 3.63 & 0.6 & 27.5 & 28.4 & 5.16 & 4.26 & 10.3 & 5.6 & $<$ LOQ & 0.48 \\
\hline $\operatorname{Ig} 11$ & 2.9 & 3.2 & 125 & 375 & 8.79 & 19.4 & 30.2 & 67.9 & 27.6 & 76.8 & 39.2 & 97.9 & 8.73 & 14.8 \\
\hline $\operatorname{Ig} 12$ & 3.1 & 3.5 & 328 & 99.1 & 12.6 & 5.0 & 3.32 & 39.3 & 2.32 & 16.9 & 76.9 & 21.3 & 9.62 & 4.62 \\
\hline $\operatorname{Ig} 13$ & 3.7 & 3.0 & 341 & 152 & 22.1 & 10.8 & 4.25 & 6.62 & 2.97 & 23.4 & 97.1 & 39.8 & 15.6 & $<\mathrm{LOQ}$ \\
\hline $\operatorname{Ig} 14$ & 4.5 & 3.0 & 285 & 84.3 & 17.5 & 3.8 & 76.0 & 13.8 & 66.7 & 15.6 & 85.3 & 22.9 & 17.9 & 2.63 \\
\hline $\operatorname{Ig} 15$ & 0.4 & 0.4 & 0.04 & $<$ LOQ & 0.07 & $<\mathrm{LOQ}$ & 0.17 & $<\mathrm{LOQ}$ & 0.15 & 0.81 & $<\mathrm{LOQ}$ & $<$ LOQ & $<$ LOQ & 2.08 \\
\hline
\end{tabular}


replication, it is not possible to attribute such differences to a seasonal trend, induced by hydrological parameters (i.e., river flow). But these results might be ascribed to a high sediment heterogeneity which, in turn, was probably derived from the presence of sandy sediments at these stations (visual observation of granulometry).

The mean concentrations of coprostanol were very similar in both samplings: $109 \pm 122 \mu \mathrm{g} \mathrm{g}^{-1}$ in the Summer sampling and $130 \pm 116 \mu \mathrm{g} \mathrm{g}^{-1}$ in the Winter sampling (Table 1). However, as also observed for TOC, the distribution of coprostanol among the stations differed considerably in many cases. At station Ig 1 , located further upstream at the Iguaçu River, the concentration of coprostanol was $1.87 \mu \mathrm{g} \mathrm{g}^{-1}$ in the Summer sampling and increased to $71.4 \mu \mathrm{g} \mathrm{g}^{-1}$ in the Winter sampling. This trend of higher coprostanol concentrations in the Summer sampling was observed in most stations, as will be discussed below. On the other hand, in opposite, it was observed in the next station (Ig2), with $249 \mu \mathrm{g} \mathrm{g} \mathrm{g}^{-1}$ of coprostanol in the Summer and $29.9 \mu \mathrm{g} \mathrm{g}^{-1}$ in the Winter samplings. Station Ig2 is influenced by the Rio Grande Farm, a rural-urban area, therefore the increasing concentration of coprostanol in the Summer, which is usually a rainy season, might be related to soil flushing by rainwater.

Station Ig3 showed high concentrations of coprostanol in both samplings (229 and $330 \mu \mathrm{g} \mathrm{g}^{-1}$, Summer and Winter samplings, respectively), indicating a high level of contamination of the Iguaçu River sediments by sewage input from the Araucária City. The other stations at the Iguaçu River downstream the Araucária City (Ig4 to Ig14) are also characterized by very high concentrations of coprostanol (65.8 to $375 \mu \mathrm{g} \mathrm{g}^{-1}$, excluding stations Ig4 and $\operatorname{Ig} 7$ in the Winter sampling), with a general trend for higher values in the Summer sampling (Table 1). At the Barigui River, the distribution of coprostanol concentrations between the samplings was similar, characterized by lower concentrations during the first sampling in the Summer (mean of $6.22 \mu \mathrm{g} \mathrm{g}^{-1}$ ) in contrast to an average of $26.0 \mu \mathrm{g} \mathrm{g}^{-1}$ in the second sampling, in the Winter. Also noteworthy, it is the high concentration of coprostanol $\left(64.7 \mu \mathrm{g} \mathrm{g}^{-1}\right)$ at station $\mathrm{Ba} 3$, located immediately downstream of the input from an industrial area. Only at station $\operatorname{Ig} 15$, the concentration of coprostanol was low (< LOD, limit of detection, $\left.0.04 \mu \mathrm{g} \mathrm{g}^{-1}\right)$ in both samplings, which indicates, therefore, no contamination at this site. This was expected as station Ig 15 is located $200 \mathrm{~km}$ downstream of the Araucária City and was considered as a reference site in our study.

A relationship was observed between coprostanol and TOC contents in the sediment (Figure 3), with a stronger positive correlation in the Summer sampling $(\mathrm{r}=0.75$, $p<0.01)$ when compared to the Winter sampling $(\mathrm{r}=0.47$, $p<0.05)$. In both samplings, however, concentrations of coprostanol above $300 \mu \mathrm{g} \mathrm{g}^{-1}$, observed at stations Ig 12 and $\operatorname{Ig} 13$ in the Summer and at stations $\operatorname{Ig} 3, \operatorname{Ig} 9$ and $\operatorname{Ig} 11$ in the Winter, were not accompanied by enhanced TOC levels. These results might reflect the influence of local processes upon the amount and distribution of coprostanol in the studied sediments, including distinct transport and sedimentation of organic materials in the rivers and/or different composition of local sources of organic matter. For example, the higher concentration of coprostanol in the Summer sampling at stations Ig12 and Ig13 (Table 1), located in the secondary channels of the Iguaçu River, suggests that these channels are contaminated by sewage only during the periods of high river flow.

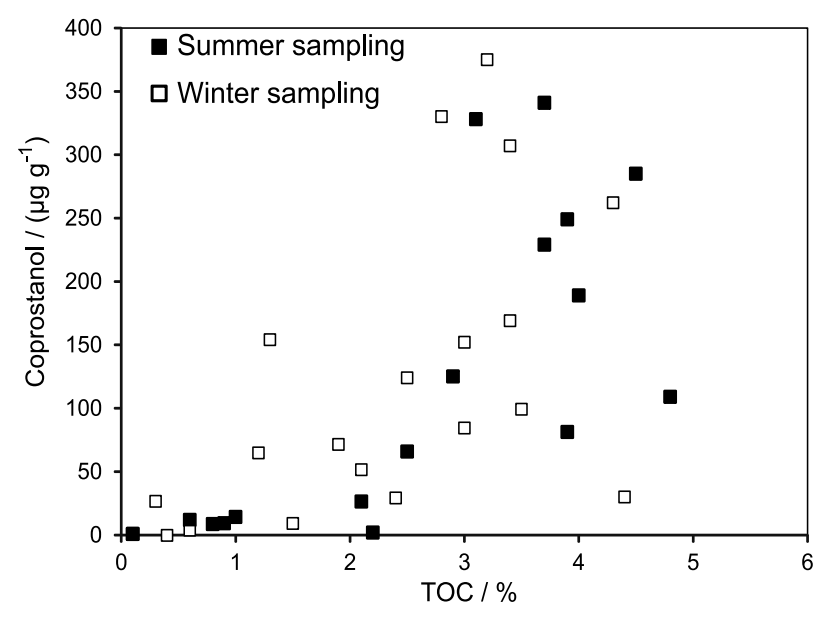

Figure 3. Relationship between coprostanol $\left(\mu \mathrm{g} \mathrm{g}^{-1}\right)$ and TOC (\%) in from the Iguaçu and the Barigui Rivers.

\section{Evaluation of the level of sewage contamination}

The use of sterols to evaluate the contamination of river systems by sewage is relatively scarce in Brazil. However, the comparison of the data available with those obtained in the present study (Table 2) suggests a high degree of sewage contamination, at least in the region where the highest concentrations of coprostanol were measured, i.e., in the main channel of the Iguaçu River (means of 101 and $246 \mu \mathrm{g} \mathrm{g}^{-1}$ in the Summer and Winter samplings, respectively). For example, rivers receiving high sewage loads located in highly urbanized regions of the Brazilian coastal zone have shown lower concentrations of coprostanol than those measured in the present study. This is the case of the Capibaribe River Estuary (Recife City, Pernambuco State, Brazil, 0.52 to $\left.7.31 \mu \mathrm{g} \mathrm{g}^{-1}\right)^{9}$ and the fluvial-estuarine zone of the Northwestern Guanabara Bay (Rio de Janeiro City, Rio de Janeiro State, Brazil, 20 to $\left.175 \mu \mathrm{g} \mathrm{g}^{-1}\right)^{7}$ Specifically regarding the Barigui River, the present set of data for coprostanol (mean of $16.1 \pm 19.9 \mu \mathrm{g} \mathrm{g}^{-1}$, 
Table 2. Coprostanol concentration in sediments from several aquatic systems worldwide

\begin{tabular}{|c|c|c|c|}
\hline Local & Type of environment & Range of concentration / $\left(\mu \mathrm{g} \mathrm{g}^{-1}\right)$ & Reference \\
\hline \multicolumn{4}{|l|}{ Brazil } \\
\hline Iguaçu and Barigui Rivers-PR & fluvial & $<0.01-375$ & this study \\
\hline Barigui River (upstream)-PR & fluvial & $0.25-196$ & 13 \\
\hline Capibaribe River-PE & fluvial-estuarine & $0.52-7.31$ & 9 \\
\hline Florianópolis-SC & lagoon & nd-2.88 & 11 \\
\hline Patos Lagoon-RS & lagoon & nd- 0.92 & 12 \\
\hline Northwestern rivers of Guanabara Bay-RJ & fluvial-estuarine & $0.21-40.8$ & 7 \\
\hline \multicolumn{4}{|l|}{ Other regions } \\
\hline Siak River, Indonesia & fluvial & $0.05-10.5$ & 19 \\
\hline Rivers in Malaysia & fluvial & $0.04-15.5$ & 16 \\
\hline Rivers in Vietnam & fluvial & $0.01-4.5$ & 16 \\
\hline Barcelona, Spain & coastal & $1.00-390$ & 17 \\
\hline Bilbao, Spain & estuarine & $2.20-293$ & 20 \\
\hline
\end{tabular}

nd: non detected.

considering both samplings) are relatively lower than values observed in the same river but at stations closer to the highly urbanized metropolitan region of the Curitiba City $\left(44.2 \pm 75.9 \mu \mathrm{g} \mathrm{g}^{-1}\right) .^{13}$ The high degree of contamination in our study region is also evident when comparing the data from rivers worldwide exhibiting problems of sewage contamination, as reported in Malaysia (0.04-15.5 $\left.\mu \mathrm{g} \mathrm{g}^{-1}\right)$ and Vietnam $\left(0.01-4.5 \mu \mathrm{g} \mathrm{g}^{-1}\right) .{ }^{16} \mathrm{In}$ fact, our data is comparable to some of the highest levels of coprostanol found in the literature, such as in the Barcelona coastal region (1.00-390 $\left.\mu \mathrm{g} \mathrm{g}^{-1}\right)^{17}$ and the Bilbao Estuary, in Spain $\left(2.20-293 \mu \mathrm{g} \mathrm{g}^{-1}\right) .^{18}$

As seen above, a wide range of coprostanol concentrations in aquatic systems can be found, and thus the establishment of a reference value to characterize sewage contamination is not straightforward. Therefore, besides the absolute concentration of coprostanol, another approach to evaluate the level of sewage contamination is the consideration of ratios among selected sterols. The three ratios usually found in the literature, alongside the threshold values suggested to indicate contamination, are shown in Table 3. The ratio coprostanol/cholesterol (Figure 4a) was well above the threshold value of 1.0 proposed for highly sewage contaminated sediments ${ }^{21}$ in all samples except station Ig15. Regarding the ratios proposed by Grimalt et al. ${ }^{17}$ with the $5 \beta$ and $5 \alpha$ isomers of sterols and stanones, if the stations $\operatorname{Ig} 1$ (wet season) and Ig15 (both seasons) are excluded, the calculated values for these ratios were above the threshold of 0.7 , indicative of sewage contamination (Figure $4 b$ ).

Considering the high level of sewage contamination in the studied sediments based on the concentration of coprostanol and diagnostic ratios, as discussed above, it is interesting to track the potential sources of sewage. This is because, in addition to domestic effluents, fecal steroids can be derived from the manure of livestock farming activities in the drainage basin or even from pets, like dogs and cats, as observed by some authors. ${ }^{3}$ The comparison of the relative proportions of $\mathrm{C}_{27}$ sterols, i.e., coprostanol, cholesterol and cholestanol, in the samples and those found in the fecal material of humans and other mammals, ${ }^{3}$ allows the identification of the sewage sources.

In Figure 5, it is shown that in most samples from the Iguaçu River the sewage source was domestic effluents (i.e., humans), particularly in the samples collected in the Summer sampling. In the Winter samples, although higher concentrations of coprostanol were observed compared to the Summer sampling (Table 1), most samples are located on the bottom of the ternary diagram, demonstrating a relative increase in the proportion of cholestanol in

Table 3. Diagnostic ratios among selected sterols and stanones

\begin{tabular}{lccc}
\hline Sterol ratio & Abbreviation & Threshold level & Reference \\
\hline (i) Coprostanol/cholesterol & cop/cholesterol & $>0.2$ : contaminated & 21 \\
& & $>1.0$ : highly contaminated & $<0.3$ : not contaminated \\
(ii) Coprostanol/(coprostanol + cholestanol) & $5 \beta /(5 \alpha+5 \beta)$ sterol & $>0.7$ : contaminated & 17 \\
(iii) Coprostanone/(coprostanone/cholestanone) & $5 \beta /(5 \alpha+5 \beta)$ stanone & $<0.3:$ not contaminated \\
& & $>0.7$ : contaminated & 17 \\
\hline
\end{tabular}



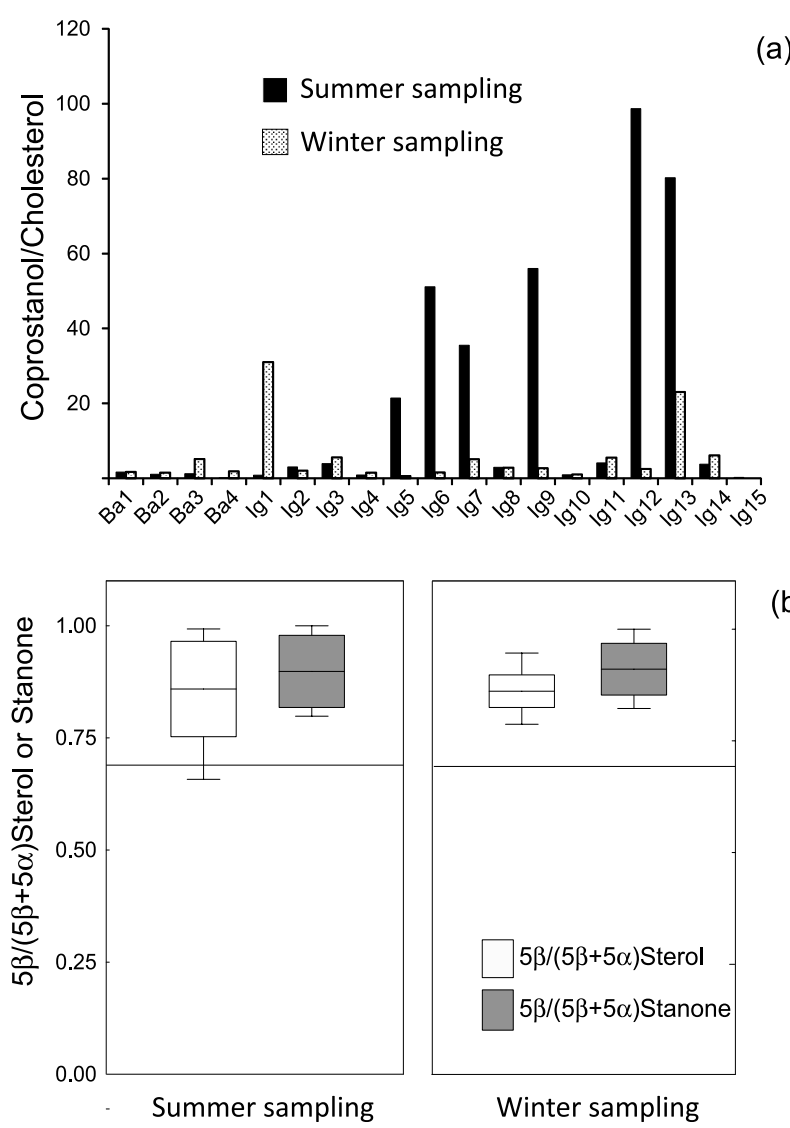

Figure 4. Diagnostic ratios of sewage contamination based on selected steroids: (a) coprostanol/cholesterol; (b) $5 \beta /(5 \beta+5 \alpha)$ stanol $=$ coprostanol/coprostanol + cholestanol and $5 \beta /(5 \beta+5 \alpha)$ stanone (excluding sample Ig15). Bar: mean, box: standard-deviation and whisker: minimum and maximum. Dashed line in (b) represents the lower threshold value (0.7) suggesting contamination by sewage

comparison to cholesterol. This suggests that in the Winter, which is usually a dry season, the sewage presented an enhanced level of degradation, as the increased contribution of cholestanol might be derived from the bacterial reduction of cholesterol and/or from autochthonous production..$^{22}$ It is noteworthy that the relative contribution of the $\mathrm{C}_{27}$ sterols also suggested contamination by pig feces,,$^{23}$ which is an important livestock in the studied region, in some stations of the Iguaçu River in both samplings (e.g., Ig3, Ig11, Ig14). In the other hand, in other stations (e.g., Ig2 and Ig8), the ratios were not similar between the two samplings, leading to inconclusive results. Moreover, Figure 5 also shows that in the Summer sampling (a wet period), the sterols in most samples from the Barigui River and stations Ig4 and Ig10 indicated the contribution of horse and cow feces. ${ }^{23}$ This can be derived from the enhanced washout from areas of livestock farming activities in the local drainage basin during periods of increased rain. Station Ba4 is located near the indication of feces from dogs. However, the concentration of steroids in this sample is low and thus

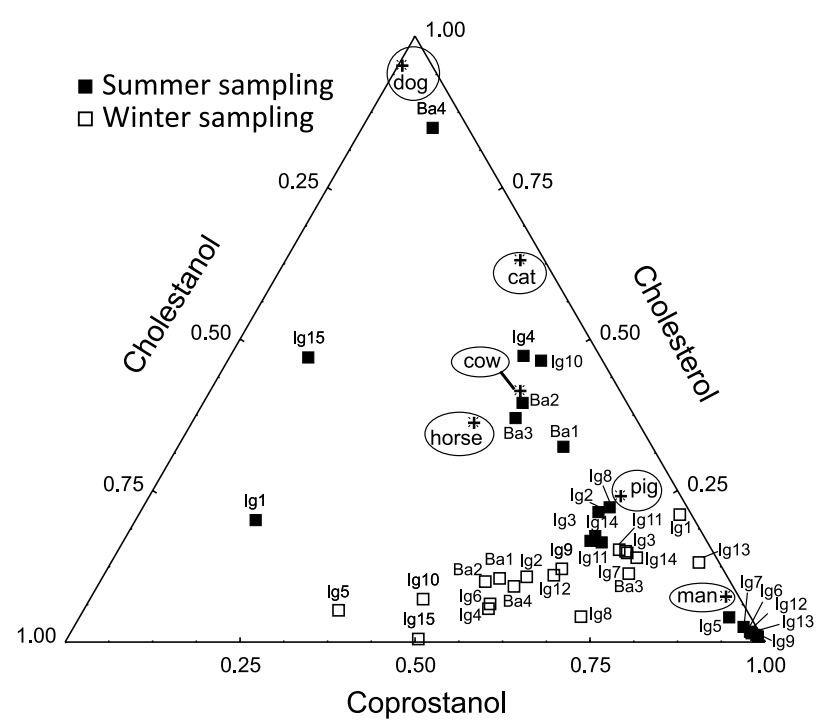

Figure 5. Ternary plot of selected sterols from sediments collected in the two samplings. Values obtained by Leeming and $\mathrm{Nichols}^{23}$ for feces from humans and other animals are indicated.

the diagnostic for Ba4 is not relevant. Finally, stations Ig1 and Ig15 from the Summer sampling are distant from any potential sewage source, which resulted from their low concentration of coprostanol.

\section{Conclusions}

Steroids were used to identify the level and sources of sewage contamination on a regional scale in a fluvial system, information that is still scarce in Brazil. When compared to other river systems around the world, coprostanol concentrations in most samples obtained from two samplings at the Iguaçu and the Barigui Rivers were extremely high, indicating an elevated degree of sewage accumulation in the sediments. Besides the input of domestic effluents, the contamination may also arise from the washout of manure produced by livestock during the rainy season, in the Summer, in some sites. The higher level of sewage contamination in the Winter sampling, a dry period, suggested a small river ability to disperse and dilute the effluents in periods of reduced water flow. In this sense, the environmental health of river systems may be more affected by the input of sewage than coastal systems, where water renewal can be more effective.

\section{Acknowledgements}

The authors thank Petrobras (Petróleo Brasileiro S.A.) through the Presidente Getúlio Vargas Refinery for funding this research through a contract with Fundação de Apoio da Universidade Federal do Rio Grande do Sul. L. Puerari and 
L. Albarello were supported by a Master fellowship from CAPES. A. Bastos Neto and R. Carreira are research fellows from CNPq. We also thank the constructive comments from an anonymous reviewer.

\section{References}

1. Huang, Q.; Yu, Y.; Tang, C.; Zhang, K.; Cui, J.; Peng, X.; J. Environ. Monitor. 2011, 13, 855; Nakada, N.; Kiri, K.; Shinohara, H.; Harada, A.; Kuroda, K.; Takizawa, S.; Takada, H.; Environ. Sci. Technol. 2009, 42, 6347; Pratt, C.; Warnken, J.; Leeming, R.; Arthur, J. M.; Grice, D. I.; Environ. Sci. Technol. 2007, 41, 792; Mudge, S. M.; Duce, C. E.; Environ. Pollut. 2005, 136, 209.

2. Isobe, K. O.; Tarao, M.; Chiem, N. H.; Min, L. Y.; Takada, H.; Appl. Environ. Microbiol. 2004, 70, 814.

3. Leeming, R.; Ball, A.; Ashbolt, N.; Nichols, P.; Water Res. 1996, 30, 2893.

4. Takada, H.; Eganhouse, R. P. In Encyclopedia of Environmental Analysis and Remediation; Meyers, R. A., eds.; John Wiley and Sons, Inc.: New York, NY, USA, 1998; Vivian, C. M. G.; Sci. Total Environ. 1986, 53, 5.

5. Bianchi, T. S.; Canuel, E. A.; Chemical Biomarkers in Aquatic Ecosystems; Princeton University Press: Princeton, NJ, USA, 2011; Eganhouse, R. P.; Molecular Markers in Environmental Geochemistry; American Chemical Society: Washington, USA, 1997.

6. Carreira, R. S.; Wagener, A. L. R.; Readman, J. W.; Estuarine Coastal Shelf Sci. 2004, 60, 587.

7. Cordeiro, L. G.; Carreira, R. S.; Wagener, A. L. R.; Org. Geochem. 2008, 39, 1097.

8. Martins, C. C.; Ferreira, J. A.; Taniguchi, S.; Mahiques, M. M.; Bícego, M. C.; Montone, R. C.; Mar. Pollut. Bull. 2008, 56, 1359; Martins, C. C.; Braun, J. A. F.; Seyffert, B. H.; Machado, E. C.; Fillmann, G.; Mar. Pollut. Bull. 2010, 60, 2137; Carreira, R. S.; Ribeiro, P. V.; Silva, C. E. M.; Farias, C. O.; Quim. Nova 2009, 32, 1805; Campos, V.; Fracácio, R.; Fraceto, L. F.; Rosa,
A. H.; Aquat. Geochem. 2012, 12, 234; Martins, C. C.; Bícego, M. C.; Figueira, R. C. L.; Angelli, J. L. F.; Combi, T.; Gallice, W. C.; Mansur, A. V.; Nardes, E.; Rocha, M. L.; Wisnieski, E.; Ceschim, L. M. M.; Ribeiro, A. P.; Sci. Total Environ. 2012, 417-418, 158; Martins, C. C.; Seyffert, B. H.; Braun, J. A. F.; Fillmann, G.; J. Braz. Chem. Soc. 2011, 22, 1585.

9. Fernandes, M. B.; Sicre, M.-A.; Cardoso, J. N.; Macedo, S. J.; Sci. Total Environ. 1999, 231, 1.

10. Araujo, M. P.; Costa, T. L. F.; Carreira, R. S.; Quim. Nova 2011, 34,64 .

11. Mater, L.; Alexandre, M. R.; Hansel, F. A.; Madureira, L. A. S.; J. Braz. Chem. Soc. 2004, 15, 725.

12. Martins, C. C.; Fillmann, G.; Montone, R. C.; J. Braz. Chem. Soc. 2007, 18, 106.

13. Froehner, S.; Maceno, M.; Martins, R.; Environ. Monit. Assess. 2010, 170, 261.

14. Pasquini, A. I.; Depetris, P. J.; J. Hydrol. 2007, 333, 385.

15. Clesceri, L. S.; Greenberg, A. E.; Eaton, A. D.; Standard Methods for the Examination of Water and Wastewater, $20^{\text {th }} \mathrm{ed}$; American Public Health Association: Washington, USA, 1999.

16. Isobe, K. O.; Tarao, M.; Zakaria, M. P.; Chiem, N.; Minh, L. Y.; Takada, H.; Environ. Sci. Technol. 2002, 36, 4497.

17. Grimalt, J. O.; Fernandez, P.; Bayona, J. M.; Albaiges, J.; Environ. Sci. Technol. 1990, 24, 357.

18. González-Oreja, J. A.; Saiz-Salinas, J.; Mar. Pollut. Bull. 1998, 36,868 .

19. Liebezeit, G.; Wöstmann, R.; Bull. Environ. Contam. Toxicol. 2010, $85,585$.

20. Gonzalez-Oreja, J. A.; Saiz-Salinas, J. I.; Estuarine Coastal Shelf Sci. 1999, 48, 391.

21. Takada, H.; Farrington, J. W.; Botner, M. H.; Johnson, C. G.; Tripp, B. W.; Environ. Sci. Technol. 1994, 28, 1062.

22. Nishimura, M.; Geochim. Cosmochim. Acta 1982, 46, 423.

23. Leeming, R.; Nichols, P. D.; Water Res. 1996, 30, 2997.

Submitted: August 21, 2012

Published online: November 30, 2012 